\title{
Pengembangan Media Pembelajaran Berbasis Android Database Komponen Listrik
}

\author{
Arif Harun Nadzar $^{1}$, Edy Supriyadi ${ }^{2}$ \\ ${ }_{1,2}$ Program Studi Pendidikan Teknik Elektro, Fakultas Teknik, Universitas Negeri Yogyakarta, Indonesia \\ 1 arif.harun2016@student.uny.ac.id* \\ *corresponding author
}

\begin{abstract}
Article Info

The purpose of this study were: (1) to develop Android-based learning media to assist the learning process of class $X$ students of Electrical Power Installation Engineering also called TITL, (2) to determine the feasibility of learning media based on material and media aspects, (3) to determine the user's response to learning media. This is a research and development with the ADDIE model. The media feasibility test uses expert judgment. This research was implemented in vocational school at SMKN 1 Pundong. The research subjects were 38 students of class X TITL. The assessment instrument uses a questionnaire with a Likert scale of four choices. The data analysis technique used descriptive analysis. The results of this research and development were: (1) the product in the form of an android application "Electrical Component Database" as a learning media at SMK $N 1$ Pundong, (2) the results of the product feasibility test by material experts obtained a score of 64 out of 72 and categorised as "Very good", The results of the product feasibility test by media experts obtained a score of 71 out of 88 and categorised as "Good ", (3) students' responses to the product obtained a mean score of 115.2 out of 140 and categorised as "Very good ".

\footnotetext{
ABSTRAK

Tujuan penelitian ini adalah: (1) mengembangkan media pembelajaran berbasis android untuk membantu proses belajar siswa kelas X Teknik Instalasi Tenaga Listrik (TITL), (2) mengetahui kelayakan media pembelajaran berdasarkan aspek materi dan media, (3) mengetahui respons pengguna terhadap media pembelajaran. Penelitian ini merupakan research and development dengan model ADDIE . Uji kelayakan media menggunakan expert judgment. Penelitian ini dilaksanakan di SMK N 1 Pundong. Subjek penelitian sebanyak 38 siswa kelas X TITL. Instrumen penilaian menggunakan kuisioner dengan skala likert empat pilihan. Teknik analisis data menggunakan analisis deskriptif. Hasil penelitian dan pengembangan ini adalah: (1) produk berupa aplikasi android "Database Komponen Listrik" sebagai media pembelajaran di SMK N 1 Pundong, (2) hasil uji kelayakan produk oleh ahli materi diperoleh skor 64 dari skor maksimal 72 dengan kategori "Sangat Layak", hasil uji kelayakan produk oleh ahli media diperoleh skor 71 dari skor maksimal 88 dengan kategori "Layak", (3) respons siswa terhadap produk diperoleh skor rerata 115,2 dari skor maksimal 140 dengan kategori "Sangat Layak".
}

Article history

Received: Nov. $18^{\text {th }}, 2020$

Revised: Nov. 30 ${ }^{\text {th }}, 2020$

Accepted: Nov. $30^{\text {th }}, 2020$

Keywords

Android,

learning media,

electrical component.
\end{abstract}




\section{PENDAHULUAN}

Berdasarkan Undang-undang Nomor 20 Tahun 2003 Pasal 18 tentang Sistem Pendidikan Nasional, Sekolah Menengah Kejuruan (SMK) merupakan jenjang pendidikan formal tingkat menengah yang ditempuh setelah lulus SMP (Sekolah Menengah Pertama), MTs (Madrasah Tsanawiyah), atau bentuk lain yang sederajat. Jenjang pendidikan tingkat menengah ini biasanya bernama SMK, MAK (Madrasah Aliyah Kejuruan), dan bentuk lain yang sederajat. Dalam melaksanakan proses pendidikan, SMK berfokus pada penyiapan kompetensi siswa untuk memasuki lapangan kerja, memberikan pengetahuan khusus sesuai bidang atau tujuan kerja yang diminati atau dipilih serta sikap profesional dalam dunia kerja melalui pembelajaran yang di berikan oleh guru.

Peran seorang tenaga pengajar atau guru sangat besar dalam menghasilkan lulusan yang memiliki kompetensi yang berkualitas dan dibutuhkan didunia usaha dan dunia kerja. Untuk mencapai tujuan itu diperlukan proses pembelajaran yang direncanakan dengan tepat seperti pembuatan silabus, rancangan pelaksanaan pembelajaran, dan pembuatan/penggunaan media pembelajaran yang tepat pula. Media pembelajaran digunakan untuk membantu guru dalam proses penyampaian informasi sehingga lebih mudah untuk diterima siswa. Media pembelajaran yang baik adalah media pembelajaran yang dapat digunakan sesuai dengan perkembangan zaman dan teknologi, sehingga akan selalu ada perkembangan yang terjadi pada media pembelajaran yang digunakan.

Guru harus dapat menyesuaikan diri mengikuti perkembangan teknologi. Di era globalisasi seperti sekarang ini telah terjadi perkembangan teknologi pada segala aspek, salah satunya teknologi telepon genggam. Contoh perkembangan telepon genggam yaitu bertambahnya fungsi telepon genggam tidak hanya untuk melakukan panggilan komunikasi tetapi juga dapat dipergunakan untuk berbagai macam hal seperti: mengakses internet, bermain game, memutar video, memutar musik, melakukan pekerjaan komputer tertentu. Nama telepon genggam berubah menjadi smartphone atau telepon pintar karena kecanggihan dan fungsi yang dimilikinya. Hal tersebut memiliki dampak positif dan juga negatif bagi pengguna. Salah satu pengguna yang dimaksud di sini adalah siswa SMK, bisa mendapatkan dampak negatif dan positif dari penggunaan smartphone. Dampak negatif yang dimaksud adalah pemanfaatan smartphone sebagian besar hanya digunakan untuk kesenangan bermain game, akses media sosial, dan menikmati hiburan, sedangkan penggunaannya untuk mendukung proses pembelajaran masih sangat sedikit.

Menurut Arsyad (2011:4), dalam proses pembelajaran terdapat dua hal penting yang harus diperhatikan oleh guru yaitu metode pembelajaran dan media pembelajaran sebagai alat bantu dalam menyampaikan ilmu. Smartphone merupakan salah satu media yang dapat digunakan sebagai alat bantu dalam menyampaikan ilmu dengan cara memanfaatkan aplikasi yang terinstal atau biasa disebut mobile application. Firdha \& Rakhmawati (2015:852) mengatakan mobile application merupakan salah satu sarana belajar yang relatif menyenangkan karena kecanggihan dan kepraktisan yang dimilikinya sehingga dapat diakses dimana saja dan kapan saja.

Berdasarkan hasil observasi yang dilaksanakan saat Pengenalan Lapangan Persekolahan (PLP) pada tanggal 15 Juli 2019 sampai 29 Agustus 2019 di SMK N 1 Pundong didapati bahwa pengetahuan siswa terhadap macam-macam komponen kelistrikan terbilang masih kurang. Siswa memiliki kendala dalam memahami dan mengingat pengetahuan komponen yang lumayan banyak, sehingga mereka harus membuka lagi referensi dari sumber yang mereka miliki. Sumber referensi yang saat ini dimiliki oleh masing-masing siswa berupa print out modul dan buku catatan tulis. Hal ini tentu kurang efektif bagi siswa karena harus mencari materi pada modul atau buku catatan tulis dengan cara membuka lembar per 
lembar catatan. Berdasarkan keterangan yang diberikan oleh siswa, mereka merasa memerlukan referensi atau media pembelajaran yang mudah untuk diakses disetiap saat mereka memerlukan.

SMK N 1 Pundong memiliki aturan yang memperbolehkan siswanya untuk membawa smartphone ke sekolah dengan syarat-syarat yang sudah ditetapkan. Akan tetapi meskipun sudah diterapkan peraturan dalam penggunaan smartphone di sekolah, dampak negatif penggunaan smartphone tetap terlihat pada siswa-siswi di SMK N 1 Pundong. Pengembangan media pembelajaran yang dapat digunakan dengan smartphone dapat menjadi solusi untuk mengatasi permasalahan tersebut sehingga dapat mengurangi dampak negatif yang ditimbulkan sekaligus membantu siswa dalam mencari informasi secara efektif.

Berdasarkan uraian permasalahan diatas diperlukan penelitian dan pengembangan aplikasi android tentang database komponen listrik sehingga membantu siswa dalam belajar atau pun mengingat kembali setiap komponenkomponen kelistrikan. Penelitian dan pengembangan ini akan menggunakan metode research and development (R\&D) dengan model pengembangan menggunakan ADDIE (Analysis, Design, Development, Implementation, Evaluation).

\section{METODE}

Penelitian ini menggunakan metode penelitian dan pengembangan atau reasearh and development (R\&D). Penelitian dilaksanakan pada bulan Juli 2020 sampai Agustus 2020 di SMK N 1 Pundong. Subjek penelitian ini terdiri dari ahli materi, ahli media, dan pengguna. Ahli materi dan ahli media masing-masing merupakan satu orang dosen dari Jurusan Pendidikan Teknik Elektro FT UNY. Pengguna sebanyak 38 siswa kelas $\mathrm{X}$ Program Keahlian TITL SMK N 1 Pundong.

Pengembangan produk menggunakan model pengembangan ADDIE yang terdiri atas Analysis, Design, Development,
Implementation, dan Evaluation. Tahap analysis bertujuan untuk mengetahui permasalahan yang ada dengan melakukan analisa situasi dan analisa masalah. Tahap design dilakukan untuk membuat rancangan awal produk yang terdiri rencana tampilan, rencana alur kerja (flowchart), dan isi dari produk. Tahap development merupakan tahap pengembangan produk dengan mengacu pada rancangan yang telah dibuat pada tahap design. Pengembangan instrumen juga dilaksanakan pada tahap ini. Tahap implementation dilakukan setelah produk mendapatkan penilaian dan perbaikan dari ahli. Implementation dilaksanakan pada subyek pengguna yang telah ditetapkan. Tahap evaluation bertujuan untuk memperbaiki kekurangan dari produk sehingga diperoleh hasil akhir produk yang lebih sempurna.

Data yang diperoleh pada penelitian ini adalah data kualitatif dan kuantitatif. Data kualitatif didapatkan melalui saran dan komentar subyek penelitian. Data kuantitatif didapatkan melalui hasil penilaian subyek penelitian dengan angket yang disusun menggunakan skala likert 4 pilihan, yaitu: sangat layak, layak, tidak layak, dan sangat tidak layak.

Instrumen digunakan untuk mengetahui kelayakan produk dan mengetahui respons pengguna. Instrumen terdiri dari aspek-aspek yang disusun sesuai dengan pengguna instrumen tersebut yaitu: ahli materi, ahli media, dan pengguna.

Pengumpulan data pada penelitian ini dilaksanakan melalui 3 tahap yaitu: (1) observasi yang dilakukan di SMK N 1 Pundong, (2) wawancara kepada siswa dan guru yang dilakukan secara spontan tanpa pedoman saat interaksi sehari-hari. (3) penilaian angket yang dibagikan kepada ahli materi, ahli media, dan pengguna.

Jenis data yang diperoleh pada penelitian ini adalah data kualitatif dan kuantitatif. Data kualitatif digunakan untuk melakukan perbaikan pada produk berdasarkan saran dan masukkan subjek penelitian. Data kuantitatif 
didapatkan melalui angket yang diberikan kepada subjek penelitian kemudian dilakukan analisis deskriptif. Angket penilaian menggunakan skala likert dengan 4 pilihan nilai untuk setiap butir pertanyaan, yaitu: 1 untuk kategori "sangat tidak setuju", 2 untuk kategori "tidak setuju", 3 untuk kategori "setuju", dan 4 untuk kategori "sangat setuju". Nilai tersebut kemudian dijumlahkan untuk mendapatkan nilai total. Nilai total kemudian dikonversikan ke dalam kategori kelayakan berdasarkan rumus Tabel 1 untuk mendapatkan kesimpulan kelayakan hasil penilaian oleh subjek penelitian. Rumus konversi kategori kelayakan dapat dilihat pada Tabel 1.

Tabel 1. Rumus Kategori Kelayakan

\begin{tabular}{cll}
\hline No & \multicolumn{1}{c}{ Interval nilai } & \multicolumn{1}{c}{ Kategori } \\
\hline 1 & $M i+1,5 S B i<x \leq \mathrm{Mi}+3 \mathrm{Sbi}$ & Sangat Layak \\
2 & $M i<x \leq \mathrm{Mi}+1,5 \mathrm{Sbi}$ & Layak \\
3 & $M i-1,5 S B i<x \leq \mathrm{Mi}$ & Tidak Layak \\
4 & $M i-3 S B i \leq \mathrm{x} \leq \mathrm{Mi}-1,5 \mathrm{Sbi}$ & Sangat Tidak \\
& & Layak \\
\hline
\end{tabular}

\section{Keterangan:}

$\mathrm{Mi}=$ Skor rata-rata ideal

$=1 / 2$ (skor ideal tertinggi + skor ideal terendah)

$\mathrm{SBi}=$ Simpangan baku ideal

$=1 / 6$ (skor ideal tertinggi - skor ideal terendah)

(Sudjana, 2014:122)

\section{HASIL DAN PEMBAHASAN}

Tahap analysis merupakan tahap awal untuk mengetahui permasalahan yang ada pada proses pembelajaran melalui 2 kegiatan yaitu analisis situasi dan analisis masalah. Analisis situasi mendapatkan hasil yaitu: jumlah siswa kelas X masing-masing adalah 35 dan 36, setiap siswa sudah memiliki smartphone, dan sumber referensi belajar siswa kurang bervariasi.

Tahap design merupakan tahap untuk merancang tampilan, alur kerja media, dan penyusunan isi dari media. Tampilan media pembelajaran akan terdiri dari beberapa halaman yaitu: halaman awal, halaman utama, halaman detail komponen, halaman tambah komponen, halaman KI \& KD, halaman kuis, dan halaman profil.

Tahap development merupakan tahap pengembangan media pembelajaran berdasarkan design yang telah dibuat. Media pembelajaran yang berupa aplikasi berbasis android dikembangkan dengan bantuan software komputer bernama android studio. Tahap pengembangan ini menghasilkan aplikasi android yang bernama "Database Komponen Listrik" dapat berjalan pada smartphone dengan system operasi minimal android 4.4. Aplikasi memiliki beberapa halaman yaitu: halaman awal, halaman utama, halaman detail komponen, halaman, halaman tambah komponen, halaman KI \& KD, halaman kuis, dan halaman profil. Terdapat navigasi untuk mengoperasikan aplikasi yaitu: tombol kembali, tombol search, tombol menu, dan tombol masuk untuk ke menu tambah komponen. Tahap development juga dilaksanakan penyusunan instrumen penelitian. Instrumen disusun berdasarkan kajian teori yang sesuai tema penelitian kemudian dibuat kisi-kisi instrumen berdasarkan responden tujuan pembagian instrumen. Kisi-kisi instrumen kemudian dikembangkan menjadi butir-butir pertanyaan. Validasi instrumen dilaksanakan oleh 2 orang ahli yang ditunjuk (expert judgment) untuk mendapatkan saran dan masukkan sebelum instrumen digunakan dalam penelitian.

Tahap implementation merupakan tahap penerapan media pembelajaran pada pengguna yaitu siswa kelas $\mathrm{X}$ TITL di SMK $\mathrm{N} 1$ Pundong. Implementation dilaksanakan setelah media mendapatkan penilaian dengan kategori minimal "layak" dan telah diperbaiki berdasarkan masukan dari ahli media dan ahli materi. Proses penyebaran angket penilaian dilakukan secara online dengan menggunakan google form sedangkan file aplikasi media pembelajaran menggunakan link google drive.

Tahap evaluasi merupakan tahap perbaikan produk sesuai saran dari ahli materi dan ahli media. Terdapat beberapa saran dari 
ahli materi, berikut ini merupakan saran yang diberikan oleh ahli materi: 1) Penambahan grafik karakteristik dari komponen seperti resistor, dioda, dan transistor FET. 2) Membedakan contoh gambar komponen yang JFET, MosFET, dan UJT. Ahli media juga memberikan beberapa saran, berikut merupakan saran dari ahli media: 1) pemilihan warna supaya lebih kontras. 2) penambahan cakupan materi supaya lebih luas, seperti menambahkan komponen dengan tegangan kerja $220 \mathrm{v}$ atau lebih. 3) tampilan supaya lebih menarik. Berdasarkan saran-saran yang diberikan dilakukan beberapa perbaikan untuk membuat produk lebih baik.

Tahap uji coba produk dilaksanakan dalam dua tahap. Tahap pertama dilakukan validasi oleh ahli materi dan ahli media (expert judgment), tahap kedua adalah implementasi produk pada pengguna (siswa). Tahap pertama bertujuan untuk mengetahui tingkat kelayakan dari produk berdasarkan penilaian ahli dan perbaikan produk berdasarkan saran dari para ahli. Tahap kedua dilaksanakan setelah produk diperbaiki dan mendapatkan penilaian dengan kategori minimal "Layak". Pada tahap ini produk diberikan kepada pengguna untuk mengetahui respons pengguna terhadap produk dengan membagikan angket instrumen penilaian yang sudah disiapkan sebelumnya.

Hasil validasi ahli materi digunakan untuk menentukan kategori kelayakan produk dari aspek materi yang tersaji dalam produk dan sebagai pedoman dalam melaksanakan revisi atau perbaikan produk. Validasi dilaksanakan oleh dosen dari Jurusan Pendidikan Teknik Elektro UNY yaitu Bapak Sigit Yatmono, ST., M.T. Berikut merupakan hasil penilaian oleh ahli materi beserta konversi kategori kelayakan.

Tabel 2. Hasil Penilaian Ahli Materi

\begin{tabular}{cccc}
\hline No & Aspek & Skor Ahli & Kategori \\
\hline 1 & Pembelajaran & 21 & Sangat layak \\
2 & Isi Materi & 43 & Sangat layak \\
& Total & 64 & Sangat layak \\
\hline
\end{tabular}

Berdasarkan Tabel 2 tersebut hasil penilaian ahli materi terhadap produk mendapatkan skor 64 dari skor maksimal 72 dengan kategori "sangat layak".

Hasil validasi ahli media digunakan untuk menentukan kategori kelayakan produk dari aspek media dan sebagai pedoman dalam melaksanakan revisi atau perbaikan produk. Berikut merupakan hasil penilaian oleh ahli media beserta konversi kategori kelayakan.

Tabel 3. Hasil Penilaian Ahli Media

\begin{tabular}{cccl}
\hline No & Aspek & Skor Ahli & \multicolumn{1}{c}{ Kategori } \\
\hline 1 & Tampilan & 43 & Layak \\
2 & Teknis & 28 & Sangat layak \\
& Total & 71 & Layak \\
\hline
\end{tabular}

Berdasarkan Tabel 3 tersebut hasil penilaian ahli media terhadap produk mendapatkan skor 71 dari skor maksimal 88 dengan kategori "layak".

Tahap implementasi dilaksanakan pada siswa kelas $\mathrm{X}$ kompetensi keahlian TITL di SMK N 1 Pundong. Responden penelitian berjumlah 38 orang siswa. Penilaian dilaksanakan menggunakan angket yang dibagikan kepada siswa. Hasil penilaian siswa menunjukkan tanggapan/respons siswa terhadap produk yang dikembangkan. Berikut ini merupakan hasil penilaian siswa terhadap produk dan konversi kategori kelayakannya.

Tabel 4. Hasil Penilaian Pengguna

\begin{tabular}{clcl}
\hline No & \multicolumn{1}{c}{ Aspek } & Rerata & \multicolumn{1}{c}{ Kategori } \\
\hline 1 & Pembelajaran & 12,8 & Baik \\
2 & Isi Materi & 30 & Sangat Baik \\
3 & Tampilan & 46,4 & Sangat Baik \\
4 & Teknis & 26 & Baik \\
& Total & 115,2 & Sangat Baik \\
\hline
\end{tabular}

Berdasarkan Tabel 4 hasil penilaian pengguna terhadap produk mendapatkan skor total ratarata sebesar 115,2 dari skor maksimal 140 dengan kategori "sangat baik".

Kajian akhir produk berupa aplikasi android bernama database komponen listrik. Aplikasi ini dapat digunakan pada smartphone dengan sistem operasi minimal android 4.4 
(kitkat). Aplikasi memiliki beberapa halaman yaitu: halaman awal, halaman utama, halaman detail komponen, halaman, halaman tambah komponen, halaman KI \& KD, halaman kuis, dan halaman profil. Terdapat navigasi untuk mengoperasikan aplikasi yaitu: tombol kembali, tombol search, tombol menu, dan tombol masuk untuk ke menu tambah komponen. Berikut ini merupakan beberapa contoh tampilan halaman yang terdapat pada aplikasi.
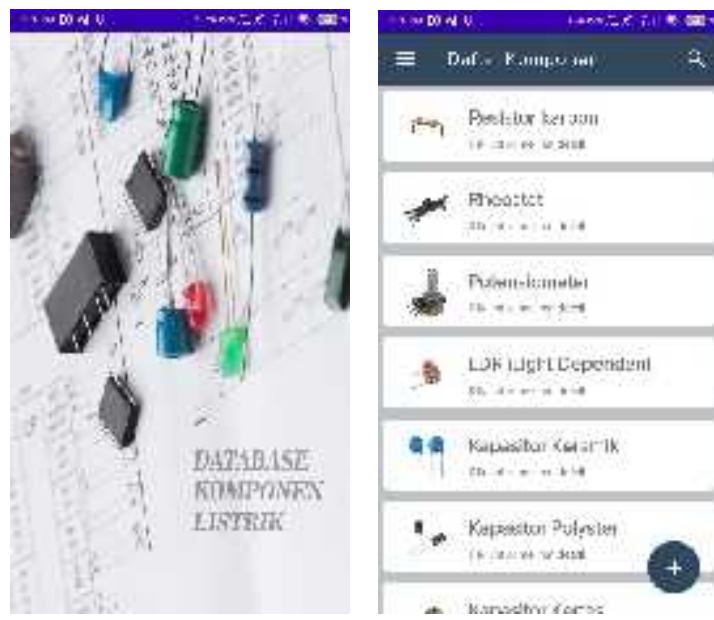

Gambar 1. Tampilan Halaman Awal \& Utama
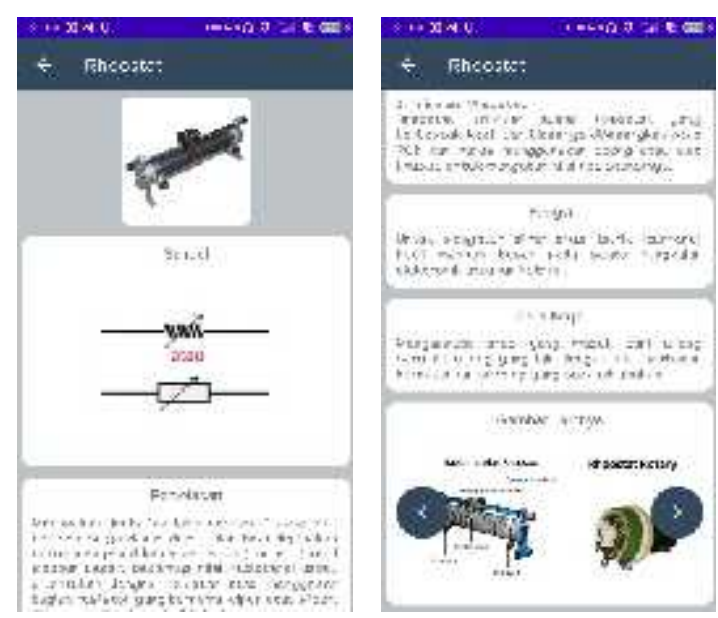

Gambar 2. Tampilan Halaman Detail Komponen

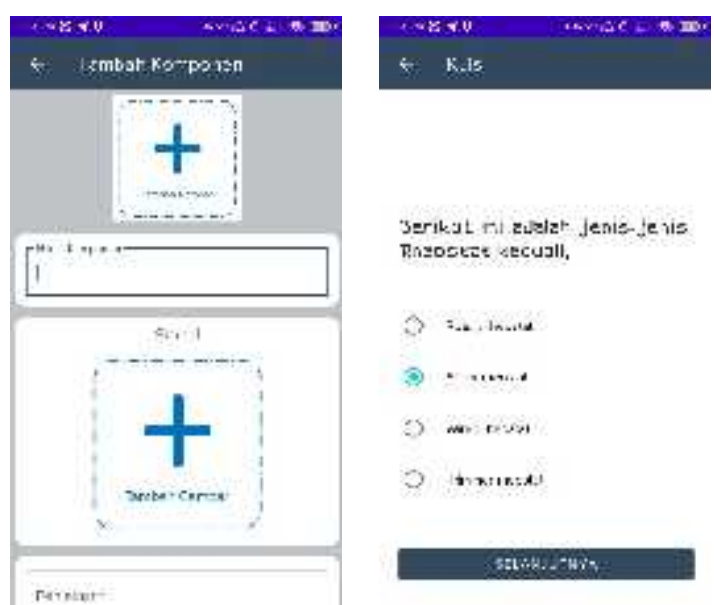

Gambar 3. Tampilan Halaman Tambah Komponen \& Kuis
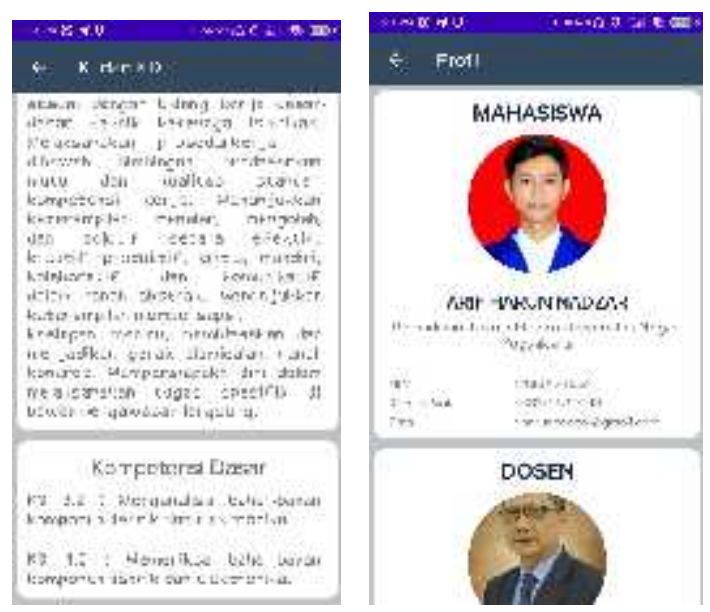

Gambar 4. Tampilan Halaman KI dan KD \& Profil

\section{SIMPULAN}

Berdasarkan hasil penelitian dan pengembangan produk yang kemudian diterapkan pada kelas X TITL di SMK N 1 Pundong didapatkan kesimpulan aplikasi "Database Komponen Listrik" sebagai media pembelajaran yang layak bagi siswa kelas $X$ TITL di SMK N 1 Pundong. Aplikasi dapat berjalan pada smartphone dengan sistem operasi minimal android 4.4 (android kitkat). Tampilan yang terdapat dalam aplikasi ini yaitu: halaman awal, halaman utama, halaman tambah komponen, halaman detail komponen, halaman kuis, halaman KI \& KD dan halaman profil. Terdapat navigasi seperti berikut ini: tombol menu, tombol kembali, tombol searching, dan 
tombol untuk mengakses halaman tambah komponen. Aplikasi ini berisi materi tentang komponen-komponen listrik seperti: ikon komponen, simbol komponen, penjelasan komponen, fungsi komponen, cara kerja komponen, dan gambar-gambar lain komponen yang tersedia di pasar.

Hasil uji kelayakan produk media pembelajaran Database Komponen Listrik dari ahli materi mendapatkan skor 64 dari skor maksimal 72 dengan kategori "Sangat Layak". Hasil uji kelayakan produk media pembelajaran Database Komponen Listrik dari ahli media mendapatkan skor 71 dari skor maksimal 88 dengan kategori "Layak". Hasil uji kelayakan produk media pembelajaran Database Komponen Listrik pada pengguna atau siswa mendapatkan skor rerata 115,2 dari skor maksimal 140 dengan kategori "Sangat Layak".

\section{DAFTAR RUJUKAN}

Arsyad, A. 2011. Media Pembelajaran. Jakarta: PT Raja Grafindo persada.
Depdikbud. 2003. Undang-Undang RI No. 20 Tahun 2003 Pasal 18 Tentang Sistem Pendidikan Nasional.

Firdha, A., \& Rakhmawati, L. 2015. Pengembangan Media Pembelajaran Mobile Application Berbasis Android Pada Mata Pelajaran Teknik Elektronika Dasar Untuk Siswa Kelas $X$ TAV Di SMK Negeri 1 Jetis Mojokerto. Pengembangan Media Pembelajaran Mobile Application Berbasis Android, 851 - 855.

Sudjana, N. 2014. Penilaian Hasil Proses Belajar Mengajar. Bandung: PT. Remaja Rosdakarya.

Tim Penyusun TAS UNY 2016. 2016. Pedoman Tugas Akhir UNY. Yogyakarta: Universitas Negeri Yogyakarta. 